\title{
The Politics of Congregational Prayer
}

\author{
Trust, Public Health, and Religious Authority in Pakistan
}

\author{
Imran Ahmed \\ School of Humanities, Arts, and Social Sciences Faculty of Humanities, \\ Arts, Social Sciences and Education University of New England, New South \\ Wales, Australia \\ iahmed5@une.edu.au
}

\begin{abstract}
Religious authorities in many Muslim-majority countries have argued that the suspension of communal prayers during an epidemic does not contravene Islamic law. In Pakistan, such measures have proven difficult to enforce, in part because many religious leaders in the country have opposed the closure of places of worship and the limits placed on public religious gatherings. The question is why? This paper suggests that the distrust of the state in matters of religion in Pakistan can be traced back to the colonial era, and that the political developments following independence have amplified frustration and mistrust between political and religious authorities in the country. Significant sources of contention in matters of religion and state remain unresolved under the prime ministership of Imran Khan. At the same time, the pandemic has thrust earlier conflicts into the spotlight and exposed contests over opinion, expertise, and authority in matters of religion and public health.
\end{abstract}

\section{Keywords}

Pakistan - coronavirus - Islamic law - religious authority - constitutional politics public health - colonization - modernization

\section{Introduction}

The spread of the novel coronavirus (sARs-CoV-2) has posed considerable governance challenges for nation states around the world striving to manage a 
fragile balance between a potential public health disaster, growing societal unrest, and dramatic economic collapse. The magnitude of these problems is far greater for low-income nations, where neither the resources nor institutions are available or able to offer adequate and accessible life-saving healthcare, enforce protective quarantine and physical distancing measures, and provide urgent welfare support and financial aid over a prolonged, unprecedented, and uncertain period of economic hardship. Further compounding the challenge of containing the disease is often the difficult, fraught, and complex relationship that exists between the governed and the governing in each individual state. Institutional trust between public authorities and citizens is a critical component in enabling successful governance responses to disasters and disease outbreaks. ${ }^{1}$ Whether it is distrust of government authorities or a challenge to government authority, the public health issues arising from a pandemic appear to be tied to the historical development of state and societal relations.

Social distancing initiatives and the imposition of lockdowns have been a critical and proven step in slowing the spread of infection and easing the pressure on healthcare systems. But despite the effectiveness of these measures, community responses to lockdowns have varied around the world. ${ }^{2}$ In the

1 See, for example, Patrick Vinck, Phuong N. Pham, Kenedy K. Bindu et al., "Institutional trust and misinformation in the response to the 2018-19 Ebola outbreak in North Kivu, DR Congo: a population-based survey", 19(5) The Lancet Infectious Diseases (2019), 529-536; Joe Trapido, "Ebola: public trust, intermediaries, and rumour in the DR Congo", 19(5) The Lancet Infectious Diseases (2019), 457-458; Van Bavel, Katherine Baicker, Paulo S. Boggio et al., "Using social and behavioural science to support CoviD-19 pandemic response", 4 Nature Human Behaviour (2020), 460-471; Chris G. Sibley, Lara M. Greaves, Nicole Satherley et al., "Effects of the COVID-19 pandemic and nationwide lockdown on trust, attitudes toward government, and well-being", 75(5) American Psychologist (2020), 618-630; Michael Siegrist \& Alexandra Zingg, "The role of public trust during pandemics: Implications for crisis communication.", 19(1) European Psychologist (2014), 23-32; Bongoh Kye \& Sun-Jae Hwang, "Social trust in the midst of pandemic crisis: Implications from Covid-19 of South Korea", 68 Research in Social Stratification and Mobility (2020).

2 In many parts of the world, government actions to impose lockdowns have resulted in legal challenges, mass demonstrations, and unrest. In large part, these responses have been the consequence of the economic impact of the virus, while elsewhere, a key issue has been concern over government overreach. In India, Iraq, and Lebanon, protestors have opposed lockdowns, which strike the poor and the most vulnerable the hardest. Liz Sly. See "Stirrings of unrest around the world could portend turmoil as economies collapse." 20 April 2020. Retrieved 8 June 2020, https://www.washingtonpost.com/world/coronavirus-protests-lebanonindia-iraq/2020/04/19/1581dde4-7e5f-11ea-84c2-0792d8591911_story.html. In Malawi, lockdown measures without provisions for a safety net have resulted in considerable social unrest and a legal challenge against the government. See Rabson Kondowe: "This country's high court blocked its coronavirus lockdown in a bid to protect the poor." 18 April 2020. Retrieved 8 June 2020, https:/qz.com/africa/1840687/malawi-court-blocks-coronaviruslockdown-to-protect-the-poor/. In New Zealand, strict lockdown measures have raised questions about whether these actions breach fundamental human rights of citizens. See Chelsea 
Islamic Republic of Pakistan, such preventative measures have proven difficult to enforce in part because many religious leaders in the country have defiantly opposed the closure of places of worship and limits on public religious gatherings. ${ }^{3}$ Although this problem is not exceptional to Pakistan, the country has unique characteristics that place it in an unusual and difficult position to reconcile and resolve the problem of limiting or banning public religious gatherings. Other nations in which Islam plays a defining role in public and political life, such as Iran, United Arab Emirates, Saudi Arabia, Algeria, Tunisia, Jordan, Kuwait, Palestine, Turkey, Syria, Lebanon, and Egypt, ${ }^{4}$ have committed to enforcing the closure of holy sites and the suspension of large public religious gatherings and congregational worship. These precautionary measures have been the subject of extensive legal discussion by traditionalist scholars of Islam worldwide, where numerous religious authorities have argued that the suspension of communal prayers and rituals in a time of epidemic does not contravene core elements of Islamic religious law when the need to adapt religious and ritual practice to extraordinary circumstances is present. ${ }^{5}$ For instance, by March 2020, many reputed Islamic scholars and institutions issued fatwas containing scriptural evidence and meticulous legal reasoning to render the temporary suspension of communal worship religiously valid and binding. ${ }^{6}$

Boyle. "Lockdown lawsuit fails: Legal action against Jacinda Ardern dismissed." 23 April 2020. Retrieved 8 June 2020, https://www.nzherald.co.nz/nz/news/article.cfm?c_id=1\&objectid= 12327116.

3 See, for example, Asif Shahzad. "'God is with us': Many Muslims in Pakistan flout the coronavirus ban in mosques." 13 April 2020. Retrieved 7 June 2020, https://www.reuters.com/article/ us-health-coronavirus-pakistan-congregat/god-is-with-us-many-muslims-in-pakistan-floutthe-coronavirus-ban-in-mosques-idUSKCN21VoT4; Maria Abi-Habib \& Zia ur-Rehman. "Imams Overrule Pakistan's Coronavirus Lockdown as Ramadan Nears." 23 April 2020. Retrieved 7 June 2020, https://www.nytimes.com/2020/04/23/world/asia/pakistan-coronavirusramadan.html.

4 INP. "President Alvi's request, Egypt's Al-Azhar issues Fatwa permitting suspension of Friday prayers." 25 March 2020. Retrieved 7 June 2020, https://nation.com.pk/25-Mar-2020/ president-alvi-s-request-egypt-s-al-azhar-issues-fatwa-permitting-suspension-of-fridayprayers.

5 Arwa Ibrahib. "Tarawih amid coronavirus: Scholars call for home Ramadan prayers." 22 April 2020. Retrieved 8 June 2020, https://www.aljazeera.com/news/2020/04/tarawih-coronavirusscholars-call-home-ramadan-prayers-200422110654018.html https://muslimmatters.org/ 2020/04/14/guidance-for-praying-tarawih-at-home/; Gyan Varma. "Govt reaches out to Muslim community ahead of Ramzan." 22 April 2020. Retrieved 6 June 2020, https://www .livemint.com/news/india/govt-reaches-out-to-muslim-community-ahead-oframzan-11587498064156.html.

6 The UAE Council for Fatwa. "Fatwa No. 11, 2020, Pertaining to the Rulings of Performing Congregational Rites in Light of the Spread of Covid-19 (Coronavirus Disease)." 3 March 2020. Retrieved 12 June 2020, http://binbayyah.net/english/wp-content/uploads/2020/03/ 
Why then has Pakistan struggled to firmly resolve the issue of suspending congregational prayer? This paper argues that grasping the complexity and development of this problem requires a broader historical perspective on the relationship between Islamic authorities and the state in Pakistan. The role and place of Islam in the state is perhaps the oldest, most contested, and ostensibly unresolved political debate in the country. This makes government policy concerning religious affairs deeply political and divisive because the clash between government and Islamic authorities is a result of mutual historical distrust and competition over authority and influence in the religious and social spheres. Some commentators have noted that tensions between politicians and the ulema in Pakistan stem from "the politics around Islamic authority," but they overlooked the fact that this is not simply a postcolonial phenomenon, although the growth in the political and social influence of religious organizations and parties has been shaped by certain constitutional, legal, and political policies instituted after independence, in $1947 .{ }^{7}$ This paper suggests that the ulema's distrust of the state goes back to the colonial era, in which the important Sunni reform movements that dominate present-day Pakistan emerged as a direct result of the fall of Muslim sovereignty in India and the political rise of British colonial rule. The loss of Muslim political power meant that the ulema had to reform Islam and reorganize its communities to ensure the survival of Islam under foreign occupation. Part of this transformation included the emergence of ulema-led political organizations and the mobilization of these bodies in the nationalist struggle for freedom and independence. But throughout the anti-colonial struggle, religious scholars displayed profound skepticism of nationalist parties and their vision for an independent India and Pakistan. The movement for Pakistan led by Muhammad Ali Jinnah was scorned by the leading ulema, who argued against both the vague and ambiguous vision of the future state and the religious credentials of the leadership.

Fatwa-11-COVID-19-final.pdf; Australian Fatwa Council. "Issued Fatwas: Coronavirus Update" 15 March 2020. Retrieved 12 June 2020, https://www.anic.org.au/wp-content/uploads/2020/04/ Important-notice-Coronavirus-Update.pdf; Egypt Independent. "Azhar scholars allow suspending Friday and congregation prayers." 15 March 2020. Retrieved 12 June 2020, https:// egyptindependent.com/azhar-scholars-allow-suspending-friday-and-congregation-prayers/; Shaykh Sayyid Muhammad al-Yaqoubi. "Friday Prayer in the UK and other countries that have been affected by the coronavirus is not obligatory." 13 March 2020. Retrieved 12 June 2020, https://www.facebook.com/LoversOfShaykhAbulHuda/videos/140634347292487/.

7 See Michael Kugelman. “Pakistan's Government Is Caught Between a Mosque and a Hard Place." 24 April 2020. Retrieved 6 June 2020, https://foreignpolicy.com/2020/04/24/pakistanramadan-coronavirus-pandemic-mosques/ ; Arsalan Khan. "Why Pakistan isn't closing mosques despite the coronavirus threat." 27 March 2020. Retrieved 5June 2020, https://www .trtworld.com/opinion/why-pakistan-isn-t-closing-mosques-despite-the-coronavirus -threat-34913. 
Independence did not change this skepticism, rather it amplified the concerns. This article demonstrates how through a sequence of constitutional and political maneuvers, political elites in Pakistan sought to placate the ulema and the Islamists without empowering them. Indeed, even with significant Islamic constitutional reforms, the ulema were sidelined from the helm of decision-making in legal and constitutional matters. Constitutionally mandated Islamic institutions are advisory. The repugnancy clause, which states that all laws must conform to Islamic principles, is justiciable under the Federal Shariat Court of Pakistan, but the jurisdiction of the Federal Shariat Court - the body responsible for aligning new and existing laws with Islamic injunctionsis limited. The consequence of these measures has been a growing frustration of the ulema and Islamist organizations, which has led to movements seeking to impose a new Islamic order of government or iron out the existing contradictions in the Constitution. The article proceeds to outline how the main sources of contention in matters of religion and state have unfolded during the prime ministership of Imran Khan. Like many of Pakistan's leaders, Imran Khan has used Islam to mobilize support for his political campaign, at the same time making sure that his Islamic vision was both vague and imprecise, and contained no real path for the ulema to be involved in political decision making. These strategic maneuvers have fomented discontent and protest. Islamic organizations have expressed their grievances and have attempted to take the government to task on important and symbolic sectarian issues, in a test to reveal the lack of political commitment of the government to Islam. Amidst these crises, response to the pandemic has brought out and thrust existing social conflicts over authority and influence over religious matters, bodies, and spaces into the spotlight. At the heart of the issue for clerics and politicians is the politics around the significance and necessity of congregational prayers at mosques across Pakistan. The article places the current contestation over Islamic authority during the CoviD-19 crisis in a broader and more nuanced historical and political context than the existing literature on the topic. Not only does the pandemic expose contests over opinion, expertise, and authority in matters of religion and religious practice, it also provides a portal into the sources of conflict and grievance between the ulema and the state, which reach back to the colonial period.

\section{2 Opposition and Defiance: authority, Public Health, and Distrust}

Pakistan found itself to be among the earliest affected countries in the fight against the new virus, in part because it shares close economic relations with countries affected early by the global outbreak and geographic proximity to 
them-China and Iran. Unlike in island nations, such as Australia and New Zealand, the politics involved in controlling the flow of labour, migration, and resources from neighboring states often complicate and impede swift border control measures for countries like Pakistan, that share territorial borders with other nations. The first cases of infection in Pakistan were recorded in late February, in patients who had recently visited Iran for pilgrimage. ${ }^{8}$ Although the Pakistani government closed its borders with Iran on February 23 and deployed emergency and preventative measures to the neighboring area, the borders were reopened for trade two weeks later, despite the fact that the Iranian state had been struggling to contain the outbreak. ${ }^{9}$

The situation proved complex because it was clear that religious gatherings posed an increasing threat to Pakistani society, as worshipers and devotees were potential vectors for the virus. The closure of the Pakistan-Iran border is a case in point. Each month, thousands of pilgrims crossed the Iran-Pakistan border, making the enforcement of a border closure difficult given the religious sensitivities of pilgrims. ${ }^{10}$ Medical and quarantine facilities were set up along the border to contain the spread of CoviD-19 between the two countries, but these measures proved to be flawed and often ineffective. "Officials closed the border," reported ur-Rehman, Abi-Habib and Mehsud, "but hundreds of Pakistanis managed to get back in anyway, either rerouting through Afghanistan to cross the border there, or bribing guards to get back in." Eventually, unsanitary conditions in the makeshift virus screening facilities along the border spread the virus among those quarantined. ${ }^{12}$

Coordinated response between different levels of government proved difficult.The passing of the 18th Amendment to the Constitution in 2010, determined that health was a province matter and placing the provincial governments

8 Ariba Shahid. "Two coronavirus cases confirmed in Pakistan - Pakistan Today." 27 February 2020. Retrieved 26 May 2020, https://www.pakistantoday.com.pk/2020/02/26/sindh -health-two-coronavirus-cases-confirmed-in-pakistan-confirms-first-coronavirus-casein-karachi/.

9 Web Desk. "Coronavirus: After 14 days, Pakistan opens Taftan border with Iran for trade.” 7 March 2020. Retrieved 3 June 2020, https://www.thenews.com.pk/latest/625285 -coronavirus-after-14-days-pakistan-opens-taftan-border-with-iran-for-trade.

10 The Nation. "Health Emergency at Iran Border." 24 February 2020. Retrieved, 1 June 2020, https://nation.com.pk/24-Feb-2020/health-emergency-at-iran-border.

11 Zia ur-Rehman, Maria Abi-Habib, \& Ihsanullah Tipu Mehsud. "'God Will Protect Us': Coronavirus Spreads Through an Already Struggling Pakistan." 23 April 2020. Retrieved 5 June 2020, https://www.nytimes.com/2020/03/26/world/asia/pakistan-coronavirustablighi-jamaat.html.

Ibid. 
of Pakistan at the forefront in the struggle against the pandemic. ${ }^{13}$ Provincial governments issued bans on public gatherings, but the response was varied, as each province faced different sets of challenges. The provincial government of Sindh complained that the federal government undermined its efforts to contain the virus because pilgrims were returning to the province without being subject to proper quarantine or isolation measures at immigration points. ${ }^{14}$ In Punjab, the largest province, the provincial government declared a health emergency, setting up facilities to screen, quarantine, and observe pilgrims returning from Iran in early March. ${ }^{15}$ But religious authorities often flouted government warnings.

The mass assemblies held by the Tablighi Jamaat, an influential Islamic organization known for its extensive evangelical work, posed serious challenges to public authorities in Pakistan. Ignoring the warnings of health and government officials, the Tablighi Jamaat hosted its annual congregation at Raiwind Markaz, in Punjab, on March 10, with 70,000-80,000 members reported to have attended. Government pressure on the organizers forced them to cut the 5-day event short, but the gathering spread the virus across Raiwind, forcing the Punjab government to lock down the city and place attendees in quarantine. This measure, however, was too little too late. Those who had attended the March congregation had spread the virus around the world from Kyrgyzstan to Gaza. ${ }^{16}$

On March 11, the World Health Organization declared the coronavirus a pandemic. ${ }^{17}$ Pakistan registered its first CoviD-19 death on March 18. Asif Ashraf Jalali, a prominent Barelwi sheikh, maintained that the All-Pakistan

13 Ashish Kumar Sen. "Pakistan's Battle with Coronavirus Reveals Governance Challenges." 19 May 2020. Retrieved 3 June 2020, https://www.usip.org/publications/2020/05/ pakistans-battle-coronavirus-reveals-governance-challenges.

14 Unrepresented Nations \& Peoples Organization. 2020. "Coronavirus: Sindh Lockdown Sabotaged?" Retrieved 8 June 2020, https://unpo.org/article/21822.

15 Web Desk. "Schools, colleges and universities in Pakistan to remain closed till April 5 amid coronavirus outbreak." 13 March 2020. Retrieved 7 June 2020, https://dailytimes .com.pk/575542/schools-colleges-and-universities-in-pakistan-to-remain-closed-till -april-5-amid-coronavirus-outbreak/.

16 Kunwar Khuldune Shahid. "How Pakistan Became a Coronavirus Super-spreader to the Entire Muslim World." 27 March 2020. Retrieved 4 June 2020, https://www.haaretz.com/ opinion/.premium-how-pakistan-became-a-coronavirus-super-spreader-to-the -muslim-world-1.8708783.

17 World Health Organisation. 2020. "WHo Director-General's opening remarks at the media briefing on COvID-19 - 11 March 2020." Retrieved 6 June 2020, https://www.who.int/dg/ speeches/detail/who-director-general-s-opening-remarks-at-the-media-briefing-on -covid-19---11-march-2020. 
Sunni Conference in Lahore on March 21 should not only go ahead, but also that if anyone were to be infected with the virus because of attending the conference, the Pakistan government should hang him. ${ }^{18}$ Muhammad Taqi Usmani, vice-president of Jamia Darul Uloom Karachi and arguably the most influential cleric in the country, declared on national television that the Prophet Muhammad had revealed the cure for the virus to a Tableeghi Jamaat member in a dream. ${ }^{19}$ In other words, influential ulema dismissed the warnings of health and state officials, and stressed that there was no serious cause for concern. These leaders encouraged the idea that faith can shield the believer from disease. ${ }^{20}$ Pir Azizur Rehman Hazarvi, an Islamabad-based cleric affiliated with the Wafaqul Madaris al Arabia, consequently stated that "the closure of mosques, shutting down Friday prayers and Taraweeh is unacceptable to the countrymen." ${ }^{21}$

Persistent disregard for health policies by the religious elite stemmed initially from distrust of government commitment to Islam. When the federal and provincial governments pushed to shut down mosques, Islamic leaders defiantly pushed back. "We can in no way close mosques... It is not possible in any circumstances in an Islamic country," explained Muneeb-bur-Rehman, a reputed Pakistani mufti and chairman of the Ruet-e-Hilal Committee. ${ }^{22}$ The identity of the state remained central in the debate on government actions that sought to curtail religious activities during the emerging crisis caused by the pandemic. Religious leaders suggested that they did not trust government decisions in matters of religion because policies to restrict public religious activities could not have stemmed from Islamic principles but as the outcome of possible foreign influence over the state. "If you do this, we will be forced to think that mosques are being deserted on America's instructions," argued

18 South Asia Media Research Institute, “\#Barelvi cleric Asif Ashraf Jalali @TheDrJalali”, 16 Mar 2020. Retrieved 6 June 2020, https://twitter.com/SAMRIReports/status/1239336926 471172108.

19 Kunwar Khuldune Shahid. "How Pakistan Became a Coronavirus Super-spreader to the Entire Muslim World." 27 March 2020. Retrieved 4 June 2020, https://www.haaretz.com/ opinion/.premium-how-pakistan-became-a-coronavirus-super-spreader-to-the-muslim -world-1.8708783.

20 Tim Hume, "Pakistan Has Banned Large Prayer Services to Prevent a Coronavirus Catastrophe. Clerics Are Holding Them Anyway." 16 April 2020. Retrieved 4 June 2020, https:// www.vice.com/en_ca/article/5dmxz8/pakistan-has-banned-large-prayer-services-to -prevent-a-coronavirus-catastrophe-clerics-are-holding-them-anyway.

$21 \quad$ Ibid.

22 Haroon Janjua. "Coronavirus and Islam: Pakistani clerics refuse to shut down mosques." $3_{1}$ March 2020. Retrieved 7 June 2020, https://www.dw.com/en/coronavirus-and-islam -pakistani-clerics-refuse-to-shut-down-mosques/a-52969639. 
Mufti Kafayatullah before a crowd. ${ }^{23}$ "We're ready to give our lives, but not ready to desert our mosques," he declared. ${ }^{24}$ Fazlur Rehman, the head of the JUI-F, similarly suggested that mosque restrictions were a conspiracy against Muslims. ${ }^{25}$

While some religious leaders noted that caution was to be exercised in public spaces, they insisted that believers could not afford to forego religious activities, including those with a communal dimension. Rather than taking cues from other Muslim countries, which had shut down mosques and suspended obligatory communal acts of worship, ${ }^{26}$ religious authorities in Pakistan moved to stress the importance of congregational activities because of the gravity of the crisis. As the holy month of Ramadan approached, Pakistan remained divided on the issue of congregational prayers.

In late March, the President Arif Alvi approached Al Azhar University in Egypt, the most preeminent Sunni Islamic institution in the world, for a fatwa (edict) permitting the suspension of Friday prayers in the country. ${ }^{27}$ In a tweet he wrote: "I am thankful to Grand Imam Shaikh of Al Azhar \& Supreme Council, for responding to my personal request to provide guidance to us with regard to Farz Jamaat \& Juma prayers in mosques during \#CoronaVirusPakistan attack. The details of Fatwa are below for our Ulema to take action." ${ }^{28}$ His efforts, however, were to no avail. "It is not possible to get rid of corona without asking God for forgiveness," stated Mufti Taqi Usmani. ${ }^{29} \mathrm{He}$ argued that

23 Asif Shahzad. "God is with us': Many Muslims in Pakistan flout the coronavirus ban in mosques." 13 April 2020. Retrieved 7 June 2020, https://www.reuters.com/article/ushealth-coronavirus-pakistan-congregat/god-is-with-us-many-muslims-in-pakistan -flout-the-coronavirus-ban-in-mosques-idUSKCN21VoT4.

24 Ibid.

25 Kalbe Ali, "Govt, ulema stand on opposite poles over congregation advisory." 16 April 2020. Retrieved 7 June 2020, https://www.dawn.com/news/1549514.

26 Lewis Sanders IV. "Coronavirus: Practising Islam amid pandemic." 28 March 2020. Retrieved 7 June 2020, https://www.dw.com/en/coronavirus-practicing-islam-amid -pandemic/a-52932856.

27 INP. "President Alvi's request, Egypt's Al-Azhar issues Fatwa permitting suspension of Friday prayers." 25 March 2020. Retrieved 6 June 2020, https://nation.com.pk/25-Mar-2020/ president-alvi-s-request-egypt-s-al-azhar-issues-fatwa-permitting-suspension-of-fridayprayers.

28 The President of Pakistan, "I am thankful to Grand Imam Shaikh of Al Azhar." 16 Mar 2020. Retrieved 6 June 2020, https://twitter.com/PresOfPakistan/status/1242774326962720768.

29 Ayesha Tanzeem. "Pakistan Clerics Insist on Keeping Mosques Open." 25 March 2020. Retrieved 7 June 2020, https://www.voanews.com/science-health/coronavirus-outbreak/ pakistani-clerics-insist-keeping-mosques-open. 
"Muslims must be in the mosques in Ramadan and pray in congregation during this time of trial" to invoke "God to end the outbreak that was sent by Him." ${ }^{30}$

\section{Ulema and the State: History of Distrust and Suspicion}

In Pakistan, a distrust of the government and the ruling elite in matters of religion has colonial origins. The rise of colonial rule and the subsequent dissolution of Muslim political sovereignty in India, in the 19th century, produced political, social, and economic conditions that spawned numerous reformist and revivalist movements across the subcontinent. These movements developed a profound distrust of colonial rule as a form of alien intrusion and a scourge for the region, and produced political theologies that sought to grasp both the loss of Muslim political power and the profound and disastrous effect that colonial occupation had on Islamic institutions and faith communities across India. ${ }^{31}$ The high stakes resulted in the emergence of numerous Muslim political organizations, including some led by traditionalist religious scholars and revivalist thinkers, seeking to advocate for Muslim interests in colonial India in the late 19th and early 20 th centuries. But the colonial state showed little interest in sharing power with its Indian subjects, despite several constitutional reforms aimed at including Indians in matters of local and provincial government. These reforms were as much measures of "divide and rule" as they were designed with the objective of keeping Indians out of the higher echelons and decision-making apparatus of the colonial state. ${ }^{32}$ The outcome of these strategies produced greater political and social competition between Muslim groups claiming to represent Islamic orthodoxy and the political interest of Indian Muslims. The freedom struggle against colonial rule witnessed the formation of rival coalitions of religious political organizations. The main

$30 \quad$ Diaa Hadid. "Pakistan Limits Worshipers At Mosques. Many Worshippers Are Defiant." 17 April 2020. Retrieved 8 June 2020, https://www.npr.org/sections/goatsandsoda/2020/ 04/17/837007264/pakistan-limits-worshippers-at-mosques-many-worshippers -are-defiant

31 Francis Robinson, "Other-Worldly and This-Worldly Islam and the Islamic Revival", 14(1) Journal of the Royal Asiatic Society (2004), 47; Francis Robinson, "Religious change and the self in Muslim South Asia since 180o", 22(1) South Asia: Journal of South Asian Studies (1999), 15 .

32 The British colonial state justified its occupation of India, in part, on the basis that Indians were too divided for independence. See Thomas R Metcalf, Ideologies of the Raj. (Cambridge: Cambridge University Press, 1994). Susan Bayly, Caste, Society and Politics in India from the Eighteenth Century to the Modern Age. (Cambridge: Cambridge University Press, 1999). 
ulema-led organization in colonial India, the Jamiat Ulema-e-Hind, ${ }^{33}$ itself split into factions over the issue of Pakistan. ${ }^{34}$ Muhammad Ali Jinnah, the future founding father of Pakistan and the leader of the Pakistan movement, argued that Muslims comprised a distinct nation in India and maintained that Islam faced a clear and present danger from the Hindu supermajority. ${ }^{35} \mathrm{He}$ led the All India Muslim League and declared that the rule of the Indian National Congress, the leading Indian nationalist party, would amount to Hindu political domination of Muslims in an independent India. ${ }^{36}$

One faction of the Jamiat Ulema-e-Hind, the Jamiat Ulema-e-Islam, supported Jinnah and the demand of the Muslim League for Pakistan, but the original organization continued to support the Indian National Congress and a unified independent India. ${ }^{37}$ Political support, however, was not same as trust. As Venkat Dhulipala has shown, the League supported numerous colonial laws and policies that adversely affected the interests, and social and religious life of Indian Muslims. ${ }^{38}$ Together with the close ties of the League with the imperial government, this made the party particularly suspicious as an anti-Islamic movement to prominent traditionalist Islamic scholars. ${ }^{39}$ Those who categorically opposed the Muslim League, such as Husain Ahmed Madani (the leader of the Jamiat Ulema-e-Hind), described its demand for Pakistan as "a death knell for the Muslims in those areas (of a partitioned India) where they were in a minority." ${ }^{40}$ Mawlana Abul Ala Mawdudi, a leading revivalist intellectual and the founding leader of the influential Jamaat-i-Islami organization, echoed this concern when he declared that Muhammad Ali Jinnah's Pakistan would "be a pagan" rather than an Islamic state. ${ }^{41}$ Although the Jamiat Ulema-e-Islam

33 The Jamiat Ulema-e-Hind was formed "with the exclusive purpose of safeguarding the Shariah and giving the Muslim community religious and political guidance according to Islamic principles and commandments." Zia-ul-Haq Faruqi, The Deoband school and the demand for Pakistan. (New York: Asia Publishing House, 1963), 68.

34 Barbara D. Metcalf, "Maulana Husain Ahmad Madani and the Jami 'at 'Ulama-i-Hind", in Ali Usman Qasmi \& Megan Eaton Robb (eds.), Muslims against the Muslim League (Cambridge: Cambridge University Press, 2017), 46-56.

35 Howard Brasted, "Islam and identity in South Asia: at the crossroads of confusion and confrontation", in N. Lahoud \& A. Johns (eds.), Islam in World Politics (New York: Routledge, 2005), 107.

36 Christophe Jaffrelot \& Cynthia Schoch, The Pakistan Paradox: Instability and Resilience. (London: London Hurst \& Company, 2015), 86-87.

37 Supra note 35 , at $44,53-56$.

38 Venkat Dhulipala, Creating a new Medina. (Cambridge: Cambridge University Press, 2015), 452-453.

39 Ibid.

40 Annemarie Schimmel, Islam in the Indian Subcontinent. (Leiden: EJ Brill, 1980), 243.

41 Ibid., 233. 
supported the Pakistan movement, the organization argued that their involvement and support for the cause was also a check on the Islamic commitment of the Muslim League. Mawlana Shabbir Usmani, the leader of the Jamiat Ulema-e-Islam, stated that "those who feared Pakistan would be ruled by the ungodly members of the All Indian Muslim League should join the League themselves and thus ensure that Pakistan was run by true Muslims." ${ }^{22}$

Muhammad Ali Jinnah kept his vision for Pakistan notoriously ambiguous and vague. ${ }^{43}$ The provinces that supported the Pakistan movement during the twilight of the Raj saw Pakistan as a steppingstone toward acquiring independent states of their own. ${ }^{44}$ Their interests, Jalal explained, were parochial, not ideological. ${ }^{45}$ Jinnah died in 1948 without resolving foundational issues related to the role and place of Islam in Pakistan. ${ }^{46}$ Jinnah balanced Islam between his religious allies and his provincial foes. He set several precedents in managing the Islamic identity of the state, which subsequent leaders of Pakistan have continued to follow. First, Jinnah used Islam as an empty signifier to legitimize his politics. Islam was whatever he wanted it to be. Leaders of Pakistan, from Liaqat Ali Khan to the current Prime Minister, Imran Khan, have followed this path of appropriating Islamic vocabulary for their own brand of politics. ${ }^{47}$ The second precedent Jinnah set was the use Islam to suppress regional identities and justify authoritarianism. In the wake of independence, Jinnah assumed the dictatorial position of the Governor General of Pakistan rather than the role of Prime Minister. He used this position to dismiss the elected governments

\section{$42 \quad$ Ibid., 243.}

43 Muhammad Qasim Zaman, "Sectarianism in Pakistan: The Radicalization of Shi'i and Sunni Identities", 32(3) Modern Asian Studies (1998), 691; Ayesha Jalal, The Sole Spokesman: Jinnah, the Muslim League and the Demand for Pakistan. (Cambridge: Cambridge University Press, 1985), 4.

44 Ibid., 118-119.

45 Ibid. Yasmin Saikia further explains: "The alliances forged between disparate groups of Muslims brought together by anxieties about survival and marginalisation at the end of British colonial rule provided the impetus to demand the creation of Pakistan as a homeland for the Muslims of the Indian subcontinent". Yasmin Saikia, "Ayub Khan and Modern Islam: Transforming Citizens and the Nation in Pakistan", 37(2) South Asia: Journal of South Asian Studies (2014), 292.

46 Ayesha Jalal maintains that "Jinnah needed a demand that was specifically ambiguous and imprecise to command general respect, and something specifically Muslim though unspecific in every other respect". Ayesha Jalal, The State of Martial Rule: The Origins of Pakistan's Political Economy of Defence (Cambridge: Cambridge University Press, 1990), 17.

47 Howard Brasted, "Islam and identity in South Asia: at the crossroads of confusion and confrontation", in N. Lahoud \& A. Johns (eds.), Islam in World Politics (New York: Routledge, 2005), 113 . 
of Sindh and the North West Frontier Province, ${ }^{48}$ and stressed the importance of Urdu - a language indigenous to Northern India rather than the areas constituting independent Pakistan - as the national language. ${ }^{49}$ "That other languages were deemed less Islamic was implicit," wrote historian Howard Brasted. ${ }^{50}$

The ulema served in an advisory capacity in the earliest constitutional deliberations, but by the early 1950s were gradually sidelined from the constitutionmaking process. This pushed them toward aggressive sectarianism to challenge the commitment of the state to Islam. Asserting a firm sectarian vision of the state meant that politicians could not get away with lip service to a vague and ambiguous Islam. The ulema formed alliances with other Islamic groups and demanded the immediate removal of foreign minister Muhammad Zafarullah Khan for being an Ahmadi - a heterodox sect of Islam. The campaign to remove the minister formed a cornerstone of the Khatam-e-Nabuwat or "the Finality of the Prophet" movement, which aimed to force the state to officially declare Ahmadis as non-Muslims. ${ }^{51}$ As demonstrations led to murders, looting and riots, civilian authorities struggled to maintain law and order, leading to the imposition of martial law in Lahore, in March $1953 .{ }^{52}$ To appease religious critics, Pakistani leaders had to concede numerous symbolic, legislative, and institutional changes to the state.

A consistent feature of the dispute over Islam is the continuing demand for the Constitution of the country to address or settle the issue. From secular politicians through to hardline militant Islamists, social and political groups across the political spectrum, including terrorist organizations, have all looked on constitutional adjustment as the way to break the impasse. The relationship and balance between the religious and the secular provisions in the current 1973 Constitution of Pakistan remains an enduring source of political and legal crises. Foundational Islamic provisions, like the preamble to the Constitution, which states that sovereignty over the entire Universe belongs to Almighty Allah alone, and the authority to be exercised by the people of Pakistan within the limits prescribed by Him is a sacred trust, remains an ambiguous and

48 Adeel Khan, Politics of Identity: Ethnic Nationalism and the State in Pakistan (New Delhi: Sage Publications, 2005), 62-63.

49 James Wynbrandt, A brief history of Pakistan. (New York: Facts on File, 2008), 173-174; Ayesha Jalal, The State of Martial Rule: The Origins of Pakistan's Political Economy of Defence (Cambridge: Cambridge University Press, 1990), 289.

5o Howard Brasted \& Adeel Khan, "Pakistan, the BJP, and the politics of identity", 25(3) South Asia:Journal of South Asian Studies (2002), 370.

51 James Wynbrandt, A brief history of Pakistan (New York: Facts on File, 2008), 174-175.

$5^{2} \quad$ Ibid. 
ambivalent statement. ${ }^{53}$ Article 227(1), which states that all laws shall conform to Islamic injunctions and that no law shall be enacted that is repugnant to such injunctions, is neither enforceable nor justiciable by the secular courts. ${ }^{54}$ The constitutional goal of realizing a just, fair, and moral society has no prescribed timeline or a defined method of achieving these objectives. ${ }^{55}$ Constitutionally mandated Islamic institutions are all advisory. ${ }^{56}$ In the late $1970 \mathrm{os}$, religious groups grew frustrated with prime minister Zulfiqar Ali Bhutto's authoritarianism, leading to the creation of the Nizam-i-Mustafa or "Order of the Prophet" movement, which comprised of a coalition of Bhutto's opposition. The protests that ensued against Bhutto led to the political intervention of the armed forces and the imposition of martial law by General Zia ul Haq.

But the project of Islamizing laws during the Zia regime have been divisive, ${ }^{57}$ and criminal law reforms such as the Hudood (which unfairly targeted women $)^{58}$ and blasphemy laws (which unfairly targeted religious minorities) ${ }^{59}$ have been met with powerful social resistance. ${ }^{60}$ Changes to the laws of evidence to make them conform to Islamic evidentiary standards were superficial. ${ }^{61}$ Zia also established the Federal Shariat Court (FSC), which has the

53 Charles Adams, "Mawdudi and the Islamic State", in John L. Esposito (ed.), Voices of Resurgent Islam (New York: Oxford University Press, 1983), 108-109.

54 Martin Lau, "Sharia and National Law in Pakistan", in Jan Michiel Otto (ed.), Sharia Incorporated: A Comparative Overview of the Legal Systems of Twelve Muslim Countries in Past and Present (Leiden: Leiden University Press, 2010), 395-396.

55 Article 31(1) states that steps shall be taken to enable the Muslims of Pakistan, individually and collectively, to order their lives in accordance with the fundamental principles and basic concepts of Islam, and to provide facilities whereby they may be enabled to understand the meaning of life according to the Holy Quran and Sunnah. The Constitution, however, gives no indication of how this will be achieved, nor does it set any time frame for the state to realize this goal.

56 Martin Lau, "Sharia and National Law in Pakistan", in Jan Michiel Otto (ed.), Sharia Incorporated: A Comparative Overview of the Legal Systems of Twelve Muslim Countries in Past and Present (Leiden: Leiden University Press, 2010), 395-396.

57 Muhammad Munir, From Jinnah to Zia (Lahore: Vanguard Books, 1979), 143; Riaz Ahmed Shaikh, "Afghan War- Global Jihad and Sectarian Conflict in Pakistan - Internal and External links", in Manas Chatterji, Darvesh Gopal, \& Savitā Singh (eds.), Governance, Development and Conflict (Bingley: Emerald Group Publishing Limited , 2011), 245.

$5^{8}$ Anita M. Weiss, "Implications of the Islamization Program for Women", in Anita M. Weiss (ed.), Islamic Reassertion in Pakistan: The Application of Islamic Laws in a Modern State (New York: Syracuse University Press, 1986), 97-113.

59 Osama Siddique \& Zahra Hayat, "Unholy speech and holy laws: Blasphemy laws in Pakistan - controversial origins, design defects, and free speech implications", 17 Minnesota Journal of International Law (2008), 303-385.

6o See Farida Shaheed, "Contested identities: Gendered politics, gendered religion in Pakistan", 31(6) Third World Quarterly (2010), 851-867.

61 Charles Kennedy, "Islamization and Legal Reform in Pakistan, 1979-1989", 63(1) Pacific Affairs (1990), 62-77. 
power to reform or repeal laws that are un-Islamic, but its constitutionally set jurisdiction is limited. The FSC comprises judges mostly from the secular courts, and appeals against its decisions can be overturned only by the Shariat Appellate Bench of the Supreme Court, which is also manned mostly by secular justices. ${ }^{62}$ Significant attempts to further Islamize laws, such as the 15th Amendment to the Constitution promulgated by Nawaz Shariff, sought to make sharia the law of the land, but failed because it was really a guise of using Islam to remove the checks and balances on the office of the Prime Minister. ${ }^{63}$

The continuing conflict concerning the meaning and implications of Islamic injunctions in the Constitution, and a long stalemate in moving Pakistan toward a specific Islamic destination, suggest that a constitutional consensus on Islam remains elusive and is the subject of vociferous public debate.

The Pakistani Taliban, for instance, have tried to ensure that the state upholds the sovereignty of God and implements the sharia. Shahidullah Shahid, former spokesman for the Pakistani Taliban, said: "My advice to the Pakistani authorities is to implement shariah in place of a sham democracy and dictatorship, and end distortions in the Constitution and there would be no armed resistance and no need for dialogue." 64 For far-right religious organizations, the proof of the Islamic character of state has become increasingly entwined with the capacity of the state to limit the political power of non-Muslim minority communities and heterodox Islamic sects.

Distrust between religious groups and the government has also undermined coordinated efforts to address important public health initiatives, such as the wHO-led polio vaccination program. Taliban suspicions of foreign public health interventions in Pakistan were heightened when it was uncovered, in

62 Muhammad Munir, Precedent in Pakistani Law (Karachi: Oxford University Press, 2014), 191. See also Articles $203 \mathrm{C}$ and $203 \mathrm{~F}$ regarding the composition of the Federal Shariat Court and the Shariat Appellate Bench. Article ${ }_{203} \mathrm{~F} 2 \mathrm{~B}(3 \mathrm{~b})$ states that not more than two ulema shall be appointed by the President to attend sittings of the Bench as ad hoc members, Article ${ }_{203} \mathrm{~F}_{2} \mathrm{~B}(3 \mathrm{a})$ states that there must be three Muslim Judges of the Supreme Court. These three judges need not be ulema.

63 Ayesha Jalal, "Pakistan's Tangle: The Politics of Conflicting Security and Economic Interests", 34(1) Government and Opposition (1999), 91.

64 He further adds: "It is incorrect to say that we don't recognise the Constitution of Pakistan; we see many distortions in it. For instance, while Article 1 of the Constitution says the country will be run by the laws ordained by the Holy Quran and the Sunnah, but another article contradicts it saying all laws will be passed by majority. This means the majority will prevail over the laws of Allah Almighty even if it is against the holy injunctions." Ahmad Hassan. "ттP Sole Guarantor of Peace: Spokesman." 4 October 2013. Retrieved 5 June 2020, http://www.thenews.com.pk/Todays-News-13-25852-TTP-sole -guarantor-of-peace\%за-spokesman. 
the aftermath of the execution of Osama bin Laden, in 2011, that CIA agents had been operating in the area under the guise of polio vaccinators. ${ }^{65}$ This meant that the global polio immunization program in the region had become embroiled in a US counterinsurgency offensive along the Afghanistan-Pakistan border. Aid workers were caught up in the Taliban insurgency against the state. ${ }^{66}$ Between December 2012 and early 2015, some 78 vaccination workers were killed in Pakistan because of the suspicions surrounding health authorities, ${ }^{67}$ intensifying conflicts between the state and the insurgents. The army clashed with the Taliban in the border regions to assume control and protect civilian vaccinators. The Pakistani Taliban argued that the polio vaccine was religiously impermissible (haram), and that vaccinators, international agencies, and the Pakistani state could not be trusted. ${ }^{68}$

Profound distrust of the state in matters of religion continues to the present day. When Imran Khan assumed power in $2018,{ }^{69}$ he promised to usher in a "New Pakistan" free of clientelism, corruption, and foreign intervention. ${ }^{70}$ His party, the Pakistan Tehreek-e-Insaf (PTI, Pakistan Movement for Justice), appeared to have ended the dominance of the two main dynastic parties that have alternated in government during democratic interregnums. The most curious item of its agenda was a declaration to recreate Pakistan as a welfare state in the image of 7 th century Madinah, under the leadership of the Prophet. Khan argued that Pakistan should be devoted to the protection and prosperity of the most vulnerable, and rebuilt along the principles of the state of Medina. In his first address as Prime Minister, he declared: "I want to share the kind of

65 Declan Walsh, "Fallout of Bin Laden Raid: Aid Groups in Pakistan Are Suspect." 2 May 2012. Retrieved 15 August 2020, https://www.nytimes.com/2012/05/03/world/asia/binladen-raid-fallout-aid-groups-in-pakistan-are-suspect.html; Donald McNeil Jr, "C. I. A. Vaccine Ruse May Have Harmed the War on Polio." July 9, 2012. Retrieved 15 August 2020, https://www.nytimes.com/2012/07/10/health/cia-vaccine-ruse-in-pakistan-may-haveharmed-polio-fight.html.

66 Robert Peckham, "Polio, terror and the immunological worldview", 13(2) Global Public Health (2018), 189-210.

67 David Hickman. "Polio wars: conspiracy and democracy in Pakistan." 18 September 2015. Retrieved 15 August 2020, https://www.opendemocracy.net/en/polio-wars-conspiracy -and-democracy-in-pakistan/.

68 Ben Doherty, "Where polio is a weapon of war." 22 December 2012. Retrieved 15 August 2020, https://www.smh.com.au/world/where-polio-is-a-weapon-of-war-20121221-2brik .html.

69 PTI won 116 out of the 272 seats contested in the National Assembly. Although the PTI fell short of the 137 seats needed to win the election outright, it managed to form a coalition government with other political parties.

70 Paul Rollier, "The lion's share: elections and democracy in Pakistan", 58(1) Commonwealth \& Comparative Politics (2020), 127. 
Pakistan I envision - the type of state that was established in Medina, where widows and the poor were taken care of... My inspiration comes from the last Prophet who set up an ideal welfare state in Medina. I want Pakistan to become like that." ${ }^{11}$

This message was striking given that Khan and the PTI balanced its progressive policies with Islamic ideals to mobilize support for the campaign. ${ }^{72}$ The new Pakistan would be the resurrection of an ancient religious state. This made Khan's political project for Pakistan quite unusual but not novel. As Dhulipala pointed out, during the freedom struggle, Mawlana Shabbir "Usmani glorified Pakistan as the first Islamic state in history that would attempt to reconstruct the Islamic utopia created by the Prophet in Medina. He constantly used Pakistan and Medina interchangeably to solidify their identification in the public mind."73 But Khan had no aspirations to recreate the theocratic state Usmani imagined. Although he sought to revive the socio-economic virtues of the ancient Arab city-state, he was silent on matters related to sharia. He courted the conservative Muslim vote while promising an egalitarian, modern, and democratic Pakistan for the progressive urban middle class. ${ }^{74}$ Khan sided with religious extremists against his political rivals on contested and symbolic matters of religion and state, ${ }^{75}$ but shied away from endorsing a legalistic view of an Islamic state devoted to the implementation of sharia. ${ }^{76}$ In this respect, his positions capture and restate the ideological ambiguities of the freedom struggle and the debates on the constitutional shape of Pakistan in the immediate aftermath of independence. His efforts to reconcile the utopian Islamic ideal of Medina with a socially and politically progressive modern democratic state are reminiscent of the contrasting slogans of the freedom struggle. ${ }^{77}$

$71 \quad$ Press Trust of India. "Will set up Medina-like welfare state in Pakistan: Imran." 26 July 2018. Retrieved 8 June 2020, http://www.ptinews.com/news/9911434_Will-set-up-Medina -like-welfare-state-in-Pakistan-Imran.

72 Ben Judah. "Pakistan's Pivot to Asia." 19 October 2018. Retrieved 8 June 2020, https://www .theatlantic.com/ideas/archive/2018/10/imran-khans-pakistan-foreshadows-globalism/ $573316 /$.

73 Venkat Dhulipala, Creating a new Medina (Cambridge: Cambridge University Press, 2015), 360.

74 Daniel Ten Kate \& Chris Kay. "Meet the New Pakistan, a Lot Like the Old Pakistan." 2 August 2018. Retrieved 7 June 2020, https://www.bloombergquint.com/businessweek/ how-pakistan-s-new-leader-imran-khan-embodies-its-old-problems.

75 Aqil Shah, "Pakistan in 2018: Theft of an Election", 59(1) Asian Survey (2019), 105.

76 Brookings. 2019. "Imran Khan's incomplete narrative on the Taliban." Retrieved 8 June 2020, https://www.brookings.edu/blog/order-from-chaos/2019/10/14/imran-khans -incomplete-taliban-narrative/.

77 Howard Brasted, Imran Ahmed, \& Saira Bano Orakzai, "Whither Pakistan: The Ambivalence of Constitutional Road Mapping?", in John Idriss Lahai, Karin von Strokirch, Howard 
But his general remarks on resurrecting the Islamic spirit of Medina were not enough for his religious critics. While Pakistani religious parties were often included in national or provincial governments as coalition partners, the period led by Imran Khan since 2018 marks a rare moment in which Islamic parties are not present in such coalitions. Not surprisingly, the most vociferous opposition to his government came from the religious right in Pakistan. Some ulema raised questions about his personal piety and religious convictions, and others have argued that the PTI pose a real and present danger to Islam in the country. The true assessment of his commitment to Islam has been tested through the question of government commitment to protect the sensibilities of Sunni Islam. Sirajul Haq, leader of the Jamaat-e-Islami in Pakistan, argued that upholding the sanctity of the Prophet was the single most important issue in the country. ${ }^{78}$ Haq maintains that economic woes, moral deterioration, and reputation for corruption stemmed from the failure of its political leadership to take matters of religion seriously and implement a genuine Islamic alternative. ${ }^{79}$

In October 2018, the Supreme Court of Pakistan acquitted Asia Bibi in a controversial and long running blasphemy case. ${ }^{80}$ Asia, a Christian woman, was charged with violating Section $295^{-C}$ of the Pakistan Penal Code, which mandates death for anyone who utters derogatory remarks against the Prophet Muhammad. ${ }^{81}$ The Court acquitted Bibi because evidence against her appeared contradictory, incoherent, and the result of a conspiracy between her accusers. ${ }^{82}$ The ruling outraged the religious right and produced mass demonstrations and social unrest against the PTI government and the higher judiciary, forcing the Court to reassess the verdict before once again confirming the original judgement. ${ }^{83}$ Government support for the verdict further led

Brasted, \& Helen Ware (eds.), Governance and Political Adaptation in Fragile States (Cham: Palgrave Macmillan, 2019), 173 .

78 News Desk. "Namoos-e-Risalat biggest issue of country: Siraj." 7 November 2018. Retrieved 8 June 2020, https://fp.brecorder.com/2018/11/20181107421818/.

79 Ibid.

8o Islamic Law Blog. 2018. "Asia Bibi v. The State: Problems of Evidence and Procedure in Pakistan." Retrieved 10 June 2020, https://islamiclaw.blog/2018/11/30/asia-bibi-v-the-state -etc-problems-of-evidence-and-procedure-in-pakistan/.

81 Section 295-C of the Pakistan Penal Code mandates death for actions and insinuations that defile the Prophet.

$82 \quad$ Asia Bibi v. The State, PLD 2019 SC 64.

83 Haseeb Bhatti. "Aasia Bibi's Final Legal Hurdle Comes to An End as sc Upholds Her Acquittal." 28 January 2019. Retrieved 7 June 2020, https://www.dawn.com/news/1460376/ aasia-bibis-final-legal-hurdle-comes-to-an-end-as-sc-upholds-her-acquittal. 
Islamic parties to proclaim that Khan and the PTI government were not serious in protecting Islam, and that this issue would be the source of Khan's ruin. ${ }^{84}$

In 2019, Mawlana Fazlur Rehman, leader of an influential wing of the Jamiat Ulema-e-Islam (known as JUI-F), declared that under Khan and the PTI "Islam was in danger." ${ }^{85}$ Rehman led anti-government protests and called his movement, established in order to force Khan to step down, the Azadi March ("freedom march"). He declared that the Azadi March was to protect the finality of the Prophet (Khatam-e-Nabuwwat). ${ }^{86}$ Tensions between the government and religious organizations have continued and ultimately impeded an effective response against the health, economic, and humanitarian crises that unfolded in Pakistan as the infection spread swiftly through the country, in early 2020.

As the pandemic unfolded in Pakistan, it became clear that the federal government needed to negotiate with religious authorities across the country because health and safety recommendations were often mocked and ignored, and lockdowns resulted in conflict between worshippers and law enforcement. ${ }^{87}$ The state lacked the resources to enforce social distancing measures and restrictions on religious gatherings. As the federal government stressed the importance of exempting some industries to revive the economy, ${ }^{88}$ religious authorities in Pakistan, aware of the weakness of the state, argued that mosques were essential and should be exempt from government-ordered shutdowns. ${ }^{89}$

84 PPI. "JI warns countrywide protest campaign amid Aasiya Bibi verdict." 4 November 2018. Retrieved 5 June 2020, https://www.pakistantoday.com.pk/2018/11/04/ji-warns -countrywide-protest-campaign-amid-aasiya-bibi-verdict/.

85 Dawn. "Govt's days are numbered, Fazlur Rehman tells PM Imran." 19 November 2019. Retrieved 8 June 2020, https://www.dawn.com/news/1517641.

86 Zaki Abbas. "Few takers for Maulana Fazl's 'Namoos-e-Risalat' politics." 28 September 2019. Retrieved 7 June 2020, https://www.pakistantoday.com.pk/2019/og/28/few-takersfor-maulana-fazls-namoos-e-risalat-politics/; Dawn. "'War' against government will only end after its fall, says Fazlur Rehman." 5 October 2019. Retrieved 8 June 2020, https://www .dawn.com/news/1509144.

87 Syed Raza Hassan. "Pakistan clerics call for lifting of congregational prayer limits." 15 April 2020. Retrieved 6 June 2020, https://www.reuters.com/article/us-health-coronavirus-pakistan-mosques/pakistan-clerics-call-for-lifting-of-congregational-prayer-limits -idUSKCN21W2MF.

88 Ibid.

89 Maria Abi-Habib \& Zia ur-Rehman. "Imams Overrule Pakistan's Coronavirus Lockdown as Ramadan Nears." 23 April 2020. Retrieved 7 June 2020, https://www.nytimes.com/2020/04/ 23/world/asia/pakistan-coronavirus-ramadan.html. 
Despite the insistence of public health experts to maintain the lockdown, ${ }^{90}$ the government reached an agreement with the ulema on April 18 to ease restrictions and keep mosques open during Ramadan, which would begin the following week. Prime Minister Khan threatened to take action against mosques that flouted safety precautions, ${ }^{91}$ but ultimately conceded the management of the religious domain to the ulema. Contesting government authority during the coronavirus crisis must be seen in historical context. The ulema's struggle against the state stemmed out of concern over the Islamic commitment of the state and suspicion over the duplicitous use of Islam and Islamic symbols by the political leadership. But the politicization of Islam is a doubleedged sword. On one hand, it accords political leaders like Khan a fragile legitimacy, on the other hand, it grants the ulema a place in politics and extensive influence over the social sphere. The relentless need for politicians and state authorities to have to negotiate with the ulema is the unwanted price and corollary of politicizing Islam. For the ulema, the pandemic provided an opportunity to showcase their authority in the social sphere. It became clear that the regulation of religious spaces, activities, and bodies of worshipers were as political as the religious laws they have long fought hard to preserve or institutionalize. When religious authorities approved of precautionary health and safety measures, they often broadcast their knowledge of public health, epidemiology, and their power to bring state authorities to the negotiating table. ${ }^{92}$ Whether it was health advice or religious advice, the ulema postured as a parallel authority to the state on mundane matters, and as a check on governmental power and policy. State efforts to bolster the religious credentials of its decrees through the fatwa from Al Azhar or by invoking the example of other Muslim countries proved largely ineffective. ${ }^{93}$ These measures were mostly ignored by prominent ulema, who selectively used such examples later, after negotiations with the state, to assert that their concerns and recommendations were

9o Geo News. “Top Pakistani doctors warn of 'fatal consequences' as government eases prayer restrictions in Ramazan." 22 April 2020. Retrieved 8 June 2020, https://www.geo.tv/ latest/284231-top-pakistani-doctors-warn-of-fatal-consequences-as-government-easesprayer-restrictions-in-ramazan.

91 Geo News. "COVID-19: PM Imran says govt will 'take action' if safety precautions are not followed in mosques." 21 April 2020. Retrieved 8 June 2020, https://www.geo.tv/latest /284115-covid-19-pm-imran-says-govt-will-take-action-if-safety-precautions-are-notfollowed-in-mosques.

$92 \quad$ M Waqar Bhatti, "Health experts, religious scholars call for following sops to prevent deaths." 30 June 2020. Retrieved 5 July 2020, https://www.thenews.com.pk/print/674157 -health-experts-religious-scholars-call-for-following-sops-to-prevent-deaths.

93 Mena Fn. "Mosques in Pakistan to remain open despite Al-Azhar Fatwa." 26 March 2020. Retrieved 30 June 2020, https://menafn.com/1099915348/Mosques-in-Pakistan-to-remain -open-despite-Al-Azhar-Fatwa. 
consistent with the sentiments of the broader Muslim world. The matter was, by and large, strictly political, not religious.

\section{$5 \quad$ Concluding Remarks}

The corona crisis raised important questions concerning how local disease outbreaks become global disasters. In Pakistan, cross-border trade and migration between neighboring states have been a source of tremendous economic benefit, regional cooperation, and mutual goodwill and close ties with adjoining nations. But porous territorial borders have also undermined the capacity to contain the virus. At the same time, Pakistan has been a center of international religious activity, and the country hosts important gatherings. Devotees attending the Tablighi Jamaat at Raiwind became vectors for the spread of the virus within the borders of the state and beyond. It became clear to public health specialists and state authorities that managing religious events would be a fundamental battle ground in the fight against the pandemic.

But responses to the disease outbreak revealed contentious and seemingly insoluble social conflicts in the country. As the state moved to limit social activity to slow the spread of the virus and ease the burden on its health system, it was met with vociferous resistance from religious authorities. This reaction appears to contrast with the responses from ulema and notable religious institutions across the Muslim world, which moved swiftly to suspend or ban communal acts of worship. In Pakistan, however, cooperation between public and religious authorities has proved challenging. It was clear that religious authorities wanted to be involved in the response to the pandemic and assert their influence and authority over religious spaces. Distrust of the state and an almost jealous and headstrong approach to protecting the autonomy of religious decision making and defending the independence of religious institutions has profound historical roots. Whether it is the deobandis, barelwis, or the tablighis, the Islamic movements that dominate Sunni religious expressions of faith in Pakistan originated as reform movements in an effort to survive the domination, intrusion, and persecution of the colonial state. Distrust of colonial authorities extended to Muslim political parties in the march toward independence. The Islamic vision of the ulema was at odds with the political leadership of Muslim parties, a recurring point of contention since the movement for the creation of Pakistan was proposed in 1940 by Muhammad Ali Jinnah. Now more than ever, a united, coordinated response between religious and political authorities is needed to manage the disaster unfolding in the country, but deep-seated historical contentions concerning the relationship between Islam and the state remain a difficult obstacle to overcome. 